\title{
Yield Ability Test of Four Genotypes Strawberries at Ciwidey District in Bandung
}

\author{
Lia Amalia ${ }^{1}$, Nunung Sondari ${ }^{2}$, Renny Yuniasari ${ }^{3}$ \\ $\left\{1\right.$ ia8264@yahoo.com $\left.{ }^{1}\right\}$ \\ Lecturer in Agrotechnology Studies Program Faculty of Agriculture, Winayamukti University, \\ Department of Agriculture Bandung District
}

\begin{abstract}
Local strawberries varieties generally have advantages that fragrant of fruit but low production because of the small size of the fruit. Farmers have been left to their local varieties, because introduced varieties have advantages in high production and larger fruit sizes but have an aromatic content that is less than the local variety. For fresh consumption, strawberries are also cultivated for industrial purposes. Each variety has the characteristics and the characteristics of each, both in flower or fruit (size and weight of the fruit). The aim of the research is to obtain local varieties in ciwidey that have high yields and to study enrich the genetic diversity of existing germplasm, hoping to netted new alleles or mutants derived from emerging from the cultivar released to farmers. The emergence of new genotypes as a result of the evaluation process, mutation, natural hybridization, and natural selection leads to the emergence of new genotypes that are superior in the sense adaptable to the environment.
\end{abstract}

Keywords: Yield ability test, strawberries, Genotypes.

\section{Introduction}

In general, the strawberries are cultivated for the purpose of fresh consumption and for industry. For fresh consumption with more emphasis on color, shape, size, flavor and aroma content, contrary to the processing industry needs total production, color and aroma [1]. Plant strawberries (Fragaria xananassa Duch) is a fruit crop with striking red and tastes sweet and fresh. Strawberry (Fragaria sp cv Holibert) is a non-climacteric fruit which has high value with high consumer demand. Tropical environment conditions can deteriorate and decrease the quality of their fruit [2]. The production of strawberries in Indonesia still does not meet market demand. The demand for strawberries in 2009 was 19,132 tons, an increase of $29.87 \%(5,714$ tons) in 2010 to 24,846 tons [3]. Until now, fruit suppliers in the Jakarta supermarkets and outside the city of Ciwidey can only supply $15-30 \mathrm{~kg}$ of strawberries from the demand of $60 \mathrm{~kg}$ per day. Strawberries in Indonesia has a great business opportunity for strawberries can be consumed fresh or processed into various kinds of foodstuffs such as syrups, jellies, dodol, jam, juice, sweets and ice cream [4]. Several varieties of processed products include pineapple and 
Bengal varieties which are often called the local varieties. Local varieties are varieties that have been there and cultivated by farmers in a long time continuously and have belonged to the public and controlled by the State. Local varieties have high adaptability to the environment. Indonesia strawberries can only grow and produce well in mountainous areas (highlands) where the air is cool [5]. Planting strawberries in areas with different environmental conditions (climate) will result these plants cannot grow and develop properly or even die [6]. Differences between the advantages of local varieties and the introduction of a very long way in terms of the weight of the fruit crop may be caused by photosynthetic translocation. Exploration is the search activity of plant genetic material in the form of genotypes, cultivars, clones, from nature as existing crop farmers or from collections or individual laboratories. The objectives of an exploration of germplasm collection is to enrich the diversity of existing germplasm. In each exploration we hope that will be netted new alleles that is not in the collection of germplasm.

\section{Methods}

The experiment was conducted in the village of Sugih Mukti, Pasir Jambu subdistrict, Bandung district with altitude of $1200 \mathrm{~m}$ above sea level. From September 2017- February 2018.

Materials used in this study is superior variety that have long been removed and survive in (Pasir Jambu, Ciwidey and Rancabali). The seeds are found of four varieties of strawberries (California, Earlibrite, Sweet Charlie, Santung), polybag, soil and compost media, NPK mutiara fertilizers.

Tools used is a hoe, little hoe, furious, knives, scissors cuttings, analytical scales and calipers .

The experiment was conducted with experimental methods implemented at screenhouse. Environmental design used was randomized block design (RBD) with simple pattern consisting of four varieties were repeated six times, so that 24 combination of treatments. The number of plants per plot was 9 plants. The number of plants per treatment was 216 plants. The distance between plants $25 \mathrm{~cm}$. The number of plants per plot samples are 3 (three) plants. Placement of treatment in each repetition is done randomly.

The treatment experiments using four varieties of strawberries that is:

$$
\begin{aligned}
& A=\text { California } \\
& B=\text { Earlibrite } \\
& \text { C }=\text { Sweet Charlie } \\
& D=\text { Santung }
\end{aligned}
$$

Observations taken of the average crop samples taken randomly without border plants. The observations were carried out are: the number of flowers, fruit length, fruit width and fruit weight. 


\section{Results And Discussion}

\subsection{The number of flowers of the strawberry plant}

The observation of the amount of interest strawberry plants can be seen in Figure 1.

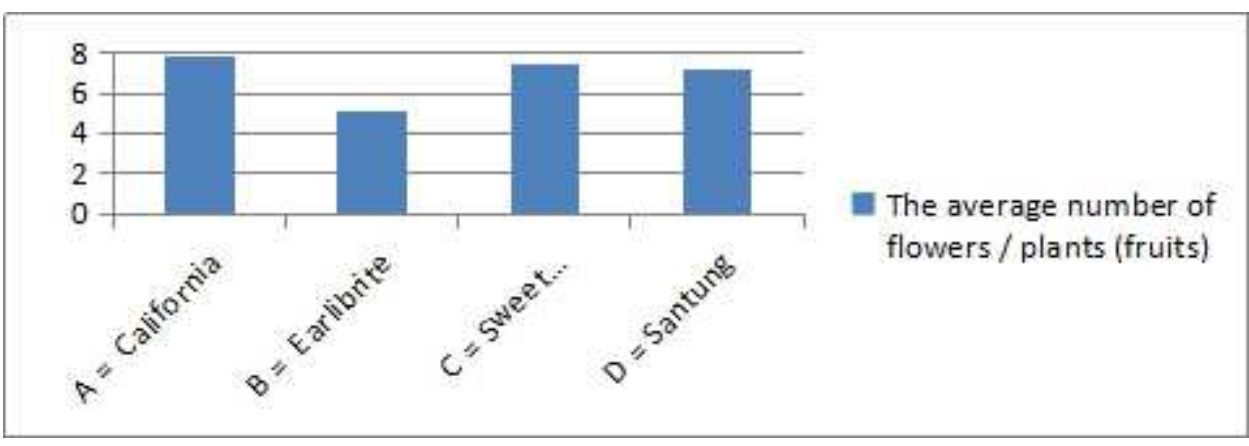

Figure 1. The number of flowers of the four strawberry varieties

Figure 1 shows that the number of flowers of California variety is significantly different with Earlibrite varieties, but no significant with Sweet Charlie and Santung varieties. This is in line with the opinions in Zainuri et al (2018) that each variety has features and characteristics of each, be it on the leaves, flowers, vines and fruit. In line with Debi Puzi Astutil's research, Arifah Rahayu2a and Hisworo Ramdani (2015), the amount of flowers is not influenced by fertilization factors (environment) but is genetically influenced (varieties). But unlike Nurlailah Mappanganro's research, Enny Lisan Sengindan Baharuddin (2019) that the amount of interest is influenced by fertilization.

\subsection{Fruit Length (cm)}

The observation of fruit length can be seen in Figure 2. 


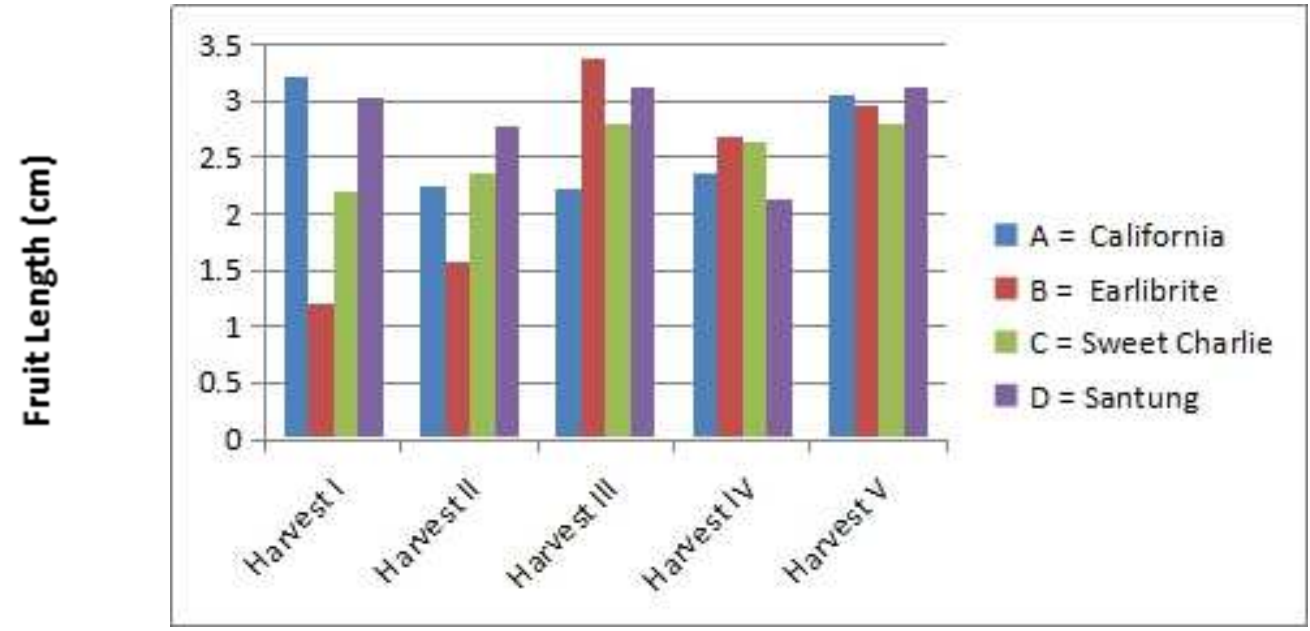

Figure 2. Fruit Length for varieties strawberry $(\mathrm{Cm})$

From Figure 2 is seen that the first harvest, California and Santung varieties have fruit length character longer than Earlibrite varieties, but not significant compared to the varieties Sweet Charlie. At 3rd harvest Earlibrite, Sweet Charlie, and Santung significantly different compared to the California variety. At 2 nd, 4 th and 5 th harvest had no significant from each other.

\subsection{Fruit width (cm)}

The result on fruit width can be seen in Figure 3.

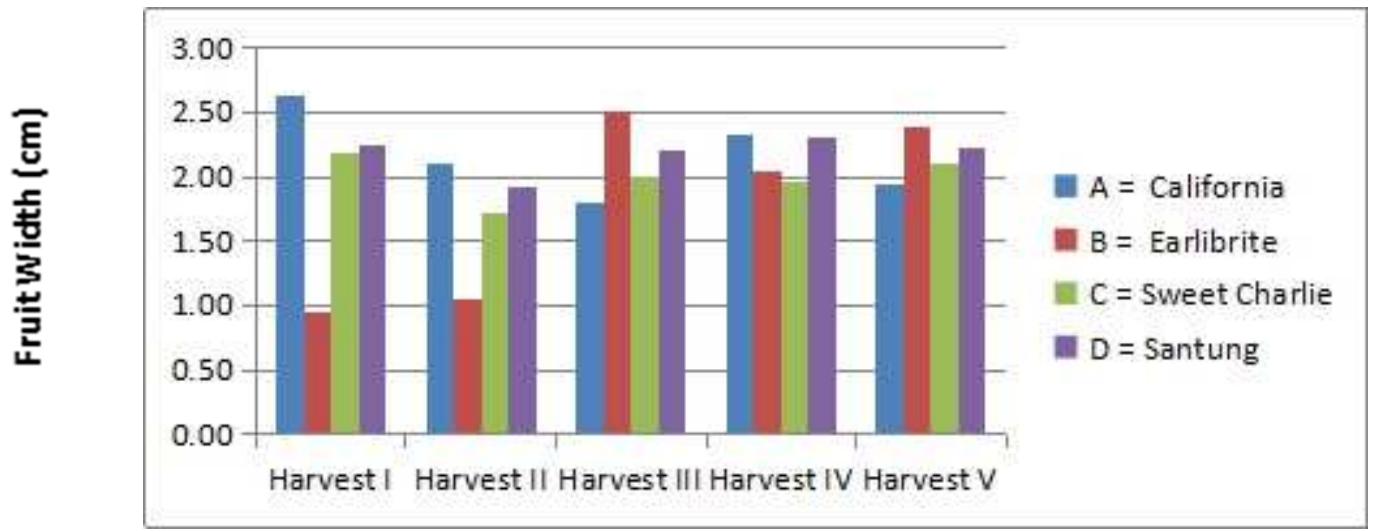

Figure 3. Fruit width four varieties strawberry 
Figure 3 showed that the width of the fruit varieties at first harvest earlibrite smaller than other varieties, but in Harvest 3rd and 5th, varieties earlibrite wider than California varieties, but not significant compared to the varieties of sweet Charlie and santung. But the harvest of the 2 nd and 4 th no significant fruit width or in another.

\subsection{Fruit weight (g)}

From Figure 4 it is seen that the harvest of all three varieties earlibrite more weight than other varieties, but for other crops were not significant. This is similar to the results of research Marlina Sipayung et al. (2016), that Earlibrite varieties give the best results at the observation parameters total wet weight of plant, total plant dry weight, number of stolon, number of harvested fruit, fruit diameter and weight of the fruit harvest. The result of the weight of the fruit can be seen in Figure 4.

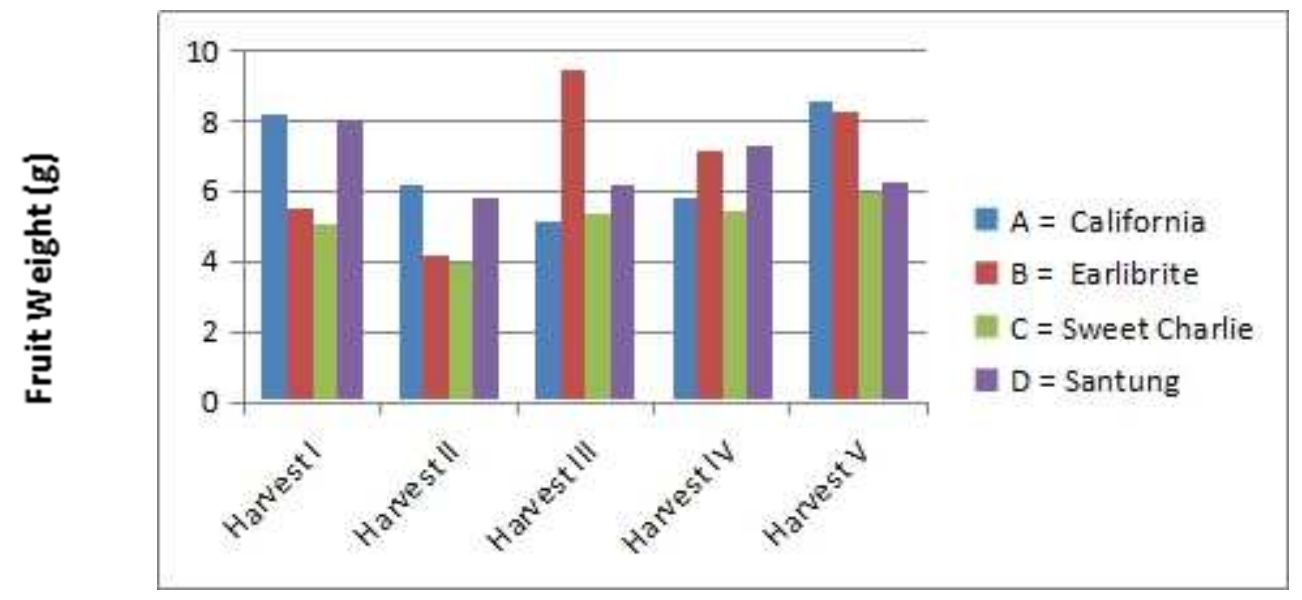

Figure 4. Fruit Weight for varieties strawberry $(\mathrm{g})$

From Figure 4 it is seen that the first harvest, Santung variety is more weight than other varieties, and the 3 rd harvest earlibrite variety is more than other varieties. At the $2 \mathrm{nd}$, 4th, 5th had no significant each other. This is similar to the results of research Marlina Sipayung et al. (2016), that Earlibrite varieties give the best results at the observation parameters total wet weight of plant, dry total plant weight, number of stolon, number of harvested fruit, fruit diameter and weight of the fruit harvest. In line with the results of Elly Kesumawati's research, Erita hayati, and Muhammad Thamrin (2012) Earlibrite varieties that are not shaded or shaded by two layers, can increase the number of leaves at 75 DAP

The use of varieties is critical to success in the growth and yield of strawberry plants. Good crop varieties are highly recommended because the use of suigig varieties or a high degree of 
adaptation is one of the determinants of high production of a commodity (Marlina Sipayung, et al., 2016).

Four superior cultivars that have long been removed and survived in this Guava, Ciwidey and Rancabali society have been regarded as local varieties and races adapted to the specific environment. The use of different varieties of strawberries affects the growth and yield of plants (Alvin Febrian Ramadhan and Didik Hariyono, 2019)

\section{Conclusions}

Eligible strawberry varieties developed in Ciwidey district. Bandung is Earlibrite and California varieties. Different strawberry varieties show diversity in plant growth and yield.

Acknowledgement. The author would like to thank all those who helped in this research. This study received research funding from the Bandung District Agriculture Office and the Seed Certification Research Institute with No SK: 521.23 / 470 / Horti / 2018.

\section{References}

[1] Abdillah Syahroni, Sri Lestari Purnamaningsih and Lita Sutopo. 2015. Quantitative and Qualitative Characters Appearance and success of Four Crosses on a variety Strawberries (Fragaria xananassa Duch). Journal of Plant Production Vol. 3. No. 5, July 2015, p. 370-376.

[2] Alvin Febrian Ramadhan dan Didik Hariyono. 2019. The Effect of Shade on Growth and Yield of Strawberry on Three Varieties (Fragaria chiloensis L.). Jurnal Produksi Tanaman. Vo;. 7 No. 1, Januari 2019. p 1-7

[3] Arjip.(19 Mei 2017).Berkebun Strawberry di Dataran Rendah. https://arjip.wordpress.com

[4] Bambang Cahyono,. 2011. Sukses Budi Daya Stroberi di Pot dan Perkebunan. Yogyakarta: Lily Publisher

[5] Badan Pusat Statistik Indonesia (BPSI). (10 Februari 2013). Produksi stroberi. http://www.badanpusatstatistikindonesia.com.

[6] Budiman S, Saraswati D. 2006. Berkebun Stroberi Secara Konvensional. Jakarta: Penebar swadaya. [7] Budiman, Supriatin dan Saraswati, D. 2006. Berkebun Stroberi secara Komersial. Penebar Swadaya. Jakarta

[8] Debi Puzi Astuti1, Arifah Rahayu2a dan Hisworo Ramdani. 2015. Jurnal Agronida ISSN: 24079111 Volume 1 Nomor 1, April 2015. P 46-56.

[9] Elly Kesumawati, Erita hayati), dan Muhammad Thamrin. 2012. The Effects of Shading and Varieties on Growth and Yield of Strawberry (Fragaria Sp.) in Lowland. Jurnal Agrista Vol. 16 No. 1, 2012. P. 14-21

[10] Lia Amalia and Nunung Sondari. Strawberries 2017. Local Variety Protection. Winayamukti University.

[11] Marlina Sipayung, Hashim Ashari, Medha Baskara and Suwasono Heddy. 2016. Effect of Compost on the Growth and Yield of Two Varieties Strawberries (Fragaria sp.). Plantropica Journal of Agriculture Science 2016 1(2). p 39-48 
[12] Mohammad Affan Fajar Falah, Putri Yuliastuti, Risma Hanifah, Pujo Saroyo and Jumeri. 2018. Quality Of Fresh Strawberry (Fragaria Sp Cv. Holibert ) From Ketep Magelang Central Java And Its Storage In Tropical Environment. Jurnal Agroindustri Vol. 8 No. 1, Mei 2018: p. 1-10

[13] Muhammad Jusuf. 2014. Germplasm. Biotechnology Research Center, Bogor Agricultural University.

[14] Nurlailah Mappanganro, Enny Lisan Sengin dan Baharuddin. (21 Agustus 2019). Growth and production of strawberry plant in various types and concentrations of organic liquid fertilizer and cow's urine with drops irrigation hydroponic system. Universitas Hasanuddin, Makasar. URL http://pasca.unhas.ac.id/jurnal/files/

[15] Vashti Rahma Hermawanti and Nur Edy Suminarti. 2018. Effect of Shading net Levels on Growth and Yield of Three Strawberry (Fragaria. Sp) Varieties in Medium Land. Plantropica Journal of Agricultural Science, p. 70-77

[16] Zainuri Hanif, Oka Ardiana Banaty, and Emi Budiyati. 2018. Varieties Effect of Maturity Levels strawberries (Fragaria xananassa) to Power Store at room temperature. Research Institute for Citrus and Subtropical Fruit, Batu, East Java. http://pascapanen.litbang.deptan.go.id 